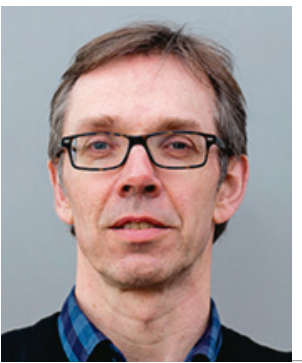

Jon Magnussen

Professor, Institutt for samfunnsmedisin, Norges teknisk-naturvitenskapelige universitet Foto: privat

\title{
Børs og katedral
}

\section{Når skal dere som aldri ser en pasient, men kun økonomi lytte? skrev en sykehuslege nylig til meg på Twitter. Hvilket grunnlag hadde nå han for å mene at vi som har økonomi som fag ikke bryr oss om pasientene?}

I den helsepolitiske debatten møter vi ofte to stereotypier: «blårussen» og «fagfolkene». Der blårussen er opptatt av bunnlinjen, er fagfolkene opptatt av pasientene. Der blårussen tenker effektivitet, tenker fagfolkene kvalitet. Der blårussen snakker om produksjon, snakker fagfolkene om pleie og omsorg. Gjennom stereotypiene dreies den helsepolitiske debatten fra å være et spørsmål om mål og virkemidler til å bli en konkurranse om hvem som bryr seg mest om pasientene.

Nylig kunne vi i Tidsskriftet lese om den uformelle doktorklubben hvor man var skjønt enige om følgende: «ldeen om å applisere tankegods hentet fra næringslivet på helsevesenet må skyldes total mangel på medisinsk innsikt. I industrien er standardisering og eliminering av variasjoner et ideal - for å øke produktiviteten, redusere kostnadene og utnytte stordriftsfordeler. En slik ideologi, som i sin natur er inhuman, vil aldri kunne passe i medisinen med dens biologiske mangfold» (1).

Intet mindre: Inhumant. I økonomifaget lærer vi at økt produktivitet, reduserte kostnader og utnyttede stordriftsfordeler gjerne fører til at det frigjøres ressurser. Disse kan igjen benyttes til å gi flere velferdstjenester til befolkningen. Flere pasienter kan få behandling, det blir rom for mer pleie og omsorg, ja kanskje kan vi til og med redde noen liv. Men dette har altså doktorklubben bestemt seg for er inhumant. Tenk det, Hedda!

$\emptyset$ konomer og leger har det til felles at de har et høyt utviklet faglig selvbilde. Men de har også ulike ståsted. Legen kan bli frustrert av hvordan handlingsrommet begrenses av budsjett og økonomi. Pasienten som har behov for helsetjenester er konkret, $\emptyset$ konomien som begrenser tilgjengeligheten til disse tjenestene er abstrakt. Der legen ser individet, ser økonomen systemet. Der legen vurderer om pasienten vil ha nytte av en tjeneste, er økonomen også opptatt av om det er andre som vil ha mer nytte av den samme tjenesten. Slik kan legen bli blind for at hans/hennes handlinger har konsekvenser ut over den enkelte pasient, og økonomen blind for at det som kan synes rasjonelt fra utsiden ikke alltid vil være det når det ses fra innsiden.

Ved å studere medisin lærer man hva sykdommer kommer av og hvordan man kan hjelpe folk til å bli friske og til å bevare god helse. Slik er medisinen (i hovedsak) et fag som er opptatt av hvordan man kan gi enkeltindividet et bedre liv. Ved å studere økonomi lærer man hvordan og på hvem samfunnet bruker sine begrensede ressurser. Slik er økonomi (i hovedsak) et fag som retter seg mot hvordan samfunnet kan få mest mulig ut av en begrenset ressursramme. I en helsetjeneste som er finansiert av og for fellesskapet blir begreper som effektivitet og fordeling derfor særlig viktige. Det er ikke et spørsmål om økonomi eller medisin, men om hvordan økonomifaget kan være verktøy som kan bidra til at vi får mest mulig pleie, omsorg og helse ut av de ressursene vi har til rådighet.

Sent i 1980-årene skulle jeg for første gang undervise helsepersonell i helse$\emptyset$ konomi. Min undervisningserfaring var begrenset til ferske økonomistudenter som stille og flittig noterte ned det foreleseren sa. Her kom jeg til en forsamling som var eldre (enn meg) og som allerede hadde skaffet seg en utdanning. Etter å ha hørt mine innledende betraktninger om nødvendigheten av å forstå begrepene effektivitet og fordeling rakk en av salens leger opp hånden og sa: «Du, det der synes jeg ikke hørtes noe interessant ut i det hele tatt!» Litt satt ut kan man trygt si at jeg ble. Dagen ble gjennomført, men om studentene lærte noe, er mer usikkert.

Siden den gangen er jeg nok blitt en bedre pedagog, og jeg opplever også at leger generelt er mer interessert i og åpne for økonomi som fag. Men det er fremdeles krevende å trekke linjene fra legenes individorienterte hverdag til økonomifagets samfunnsfokus. Det er allikevel vårt ansvar som har økonomi som fag å formidle vårt faglige tankegods på en slik måte at det oppleves som både relevant og interessant for leger og annet helsepersonell. Det gjør vi best når vi tar med oss forståelse og respekt for den hverdagen legene befinner seg i. Til gjengjeld må også vi bli møtt med respekt for at vi representerer et fag som har sine innarbeidede begreper, tankemåter og terminologi. Ikke minst må vi slippe å bruke krefter på å argumentere for at vi er like gode mennesker som leger og annet helsepersonell. Legestudiet gir autorisasjon for å praktisere medisin, men det gir på ingen måte noe monopol på medmenneskelighet.

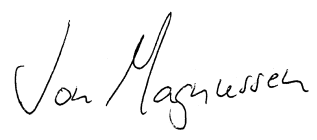

\section{Litteratur}

1. Nakken K. O. Om bunnlinjer og pasientavtaler. Tidsskr Nor Legeforen 2015; 135: 1164. 